\title{
PENGARUH KUALITAS PELAYANAN TERHADAP KEPUASAN NASABAH PADA PT. BANK RAKYAT INDONESIA (PERSERO) Tbk.UNIT BENGO CABANG WATAMPONE
}

\author{
Samsul Rizal \\ samsulrizal@unismuh.ac.id \\ Fakultas Ekonomi dan Bisnis \\ Universitas Muhammadiyah Makassar \\ Abd Rahman Rahim \\ abdrahmanrahim@unismuh.ac.id \\ Fakultas Ekonomi dan Bisnis \\ Universitas Muhammadiyah Makassar \\ Eka Wardiana \\ ekawardiana@gmail.com \\ Fakultas Ekonomi dan Bisnis \\ Universitas Muhammadiyah Makassar
}

\begin{abstract}
The purpose of this study was to determine the effect of service quality on customer satisfaction at PT. Bank Rakyat Indonesia (Persero) Tbk. Unit Bengo Branch Watampone. This research was conducted at PT. Bank Rakyat Indonesia (Persero) Tbk. Unit Bengo Branch Watampone, the research population is all customers of PT. Bank Rakyat Indonesia (Persero) Tbk. Unit Bengo Branch Watampone Unit which was met at the time of the research, where the population was 500 customers while the sample size was determined using incidental sampling technique, which was 84 respondents. Data collection uses descriptive statistical techniques, simple linear regression analysis, and hypothesis testing. The results of data analysis obtained $t$ count of 7.669 while $t$ table amounted to 1.98932, so the $t$ test hypothesis variable service quality has a positive effect on customer satisfaction. From the calculation of SPSS obtained $R=0.646$, with $R 2=0.418$ or $41.8 \%$, the amount of customer satisfaction has been explained in the service quality data. While the rest, which is 0.582 or $58.2 \%$, information about the amount of customer satisfaction cannot be explained by these independent variables.
\end{abstract}

Keywords: Service Quality, Customer Satisfaction

\begin{abstract}
Abstrak
Tujuan penelitian ini adalah untuk mengetahui Pengaruh Kualitas Pelayanan Terhadap Kepuasan Nasabah pada PT. Bank Rakyat Indonesia (Persero) Tbk. Unit Bengo Cabang Watampone. Penelitian ini dilaksanakan pada PT. Bank Rakyat Indonesia (Persero) Tbk. Unit Bengo Cabang Watampone, populasi penelitian adalah semua nasabah PT. Bank Rakyat Indonesia (Persero) Tbk. Unit Bengo Cabang Watampone yang ditemui pada saat penelitian, dimana populasinya sebanyak 500 nasabah sedangkan besarnya sampel yang ditetapkan menggunakan teknik insidental sampling yaitu sebanyak 84 responden. Pengumpulan data menggunakan teknik statistik deskriptif, analisis regresi linear sedehana, dan uji hipotesis. Hasil analisis data diperoleh t hitung sebesar 7.669 sedangkan t tabel sebesar 1.98932, sehingga hipotesis uji t variabel kualitas pelayanan memiliki pengaruh yang positif terhadap kepuasan nasabah. Dari hasil perhitungan SPSS diperoleh $\mathrm{R}=$ 0,646 , dengan $\mathrm{R}^{2}=0,418$ atau $41,8 \%$, dari besarnya kepuasan nasabah telah dijelaskan pada data kualitas pelayanan. Sementara sisanya yaitu 0,582 atau $58,2 \%$ informasi mengenai besarnya kepuasan nasabah belum dapat dijelaskan oleh variabel-variabel bebas tersebut.
\end{abstract}

Kata Kunci: Kualitas Pelayanan, Kepuasan Nasabah. 


\section{PENDAHULUAN}

Bank merupakan mata rantai antara penabung dan pemakai uang. Dengan demikian bank merupakan suatu perusahaan yang pekerjaannya mengelola kebutuhan-kebutuhan kredit sebab dari seluruh uang yang disimpan atau di tabungkan pada bank, oleh bank itu dipinjamkan lagi kepada mereka atau pengusaha yang memerlukan kredit. Bank hidup dari selisih bunga yang dipungut dari para peminjam ke bank tersebut dengan bunga yang diberikan kepada para penyimpan/penabung.

Dunia perbankan Indonesia saat ini diwarnai dengan persaingan yang semakin ketat. Hal ini di karenakan semakin majunya lembaga-lembaga perbankan dan lembaga perkreditan yang berusaha menarik perhatian nasabah. Dengan semakin banyak lembaga perbankan dan lembaga perkreditan, sudah barang tentu masyarakat mempunyai berbagai alternatif dalam menggunakan jasa perbankan. Dalam upaya menciptakan kepuasan nasabah, pihak bank seharusnya melakukan evaluasi terhadap tingkat pelayanan yang diberikan kepada nasabah sehingga menghasilkan kepuasan nasabah terhadap bank yang dinaunginya.

Perjuangan untuk menciptakan bisnis yang berulang dengan nasabah yang sudah ada di tangan menempati titik sentral dalam upaya bank untuk tetap unggul dalam persaingan jangka panjang. Memang kini pelayanan yang diterima nasabah sudah dijadikan standar dalam hal menilai kinerja sebuah bank. Dengan adanya likuiditas yang merupakan kesanggupan dan kemampuan dari bank itu untuk sewaktu-waktu penyimpan uang memerlukan kembali uangnya, dapat terpenuhi oleh bank tersebut.
Bank yang selalu likuid akan selalu mendapat kepercayaan penuh dari para nasabahnya, yang berarti para penitip akan berdatangan secara terus menerus untuk menyimpan modalnya pada bank yang bersangkutan. Kepuasan adalah suatu proses yang dinamis secara berkala oleh suatu perusahaan manufaktur atau jasa. Karena pada dasarnya kepuasan inilah yang menghasilkan profit atau revenue pada perusahaan. Kepuasan dapat berubah, hal ini dikarenakan tingkat ekspektasi atau harapan semakin tinggi, sehingga menuntut adanya kualitas yang lebih. Meningkatnya tingkat pesaingan terutama dalam bidang perbankan, termasuk aktivitas promosi informasi dan janji yang diterima nasabah ini akhirnya menaikkan harapan nasabah.

Oleh karena itu, salah satu upaya yang dilakukan oleh setiap perusahaan khususnya pada perusahaan yang bergerak di bidang jasa perbankan, tepatnya pada PT. Bank Rakyat Indonesia (Persero) Tbk. Unit Bengo Cabang Watampone adalah dengan menerapkan masalah kualitas pelayanan. Kualitas pelayanan adalah sebagai upaya pemenuhan kebutuhan dan keinginan konsumen atau nasabah serta ketepatan penyampaiannya dalam mengimbangi harapan nasabah. Dimana dalam menunjang pengelolaan aktivitas perbankan maka perlu adanya tingkat pelayanan nasabah, sebab dengan adanya tingkat pelayanan nasabah maka akan memberikan kepuasan bagi nasabah.

Program pelayanan nasabah (Customer Service) di suatu bank bagi para nasabahnya khususnya pada PT. Bank Rakyat Indonesia (Persero) Tbk. Unit Bengo Cabang Watampone menyangkut faktor-faktor yang mempengaruhi penilaian nasabah atas pelayanan yang diterima seperti: 
penampilan dan kerapihan karyawan (bukti langsung), kemampuan karyawan dalam menanggapi masalah yang dihadapi nasabah (kehandalan), kesungguhan karyawan dalam membantu nasabah (daya tanggap), profesionalisme karyawan dalam bekerja (jaminan), keramahan dan kesopanan karyawan dalam menghadapi nasabah (empati). Pada dasarnya pelayananlah yang menjadi faktor terpenting dalam menentukan kepuasan nasabah.

Demikian halnya dengan Sarah Setirah (2012) yang meneliti mengenai Analisis pengaruh kualitas pelayanan terhadap kepuasan nasabah penabung pada PT. Bank Sulselbar di Makassar, dimana dimensi kualitas layanan dengan kepuasan nasabah yaitu : tangible, reliability, responsiveness, assurance dan emphaty yang menunjukkan bahwa kelima dimensi kualitas layanan berpengaruh terhadap peningkatan kepuasan nasabah.

Kondisi dan tempat pada PT. Bank Rakyat Indonesia (Persero) Tbk. Unit Bengo Cabang Watampone sangat strategis, sehingga mudah dijangkau oleh nasabah. Dilihat juga dari segi pelayanan yang diberikan oleh perusahaan kepada nasabah terbilang cukup baik, namun masih ada masalah yang sering timbul yaitu kurangnya informasi tentang produk bank yang disampaikan ke nasabah sehingga membuat nasabah kurang memahami dan mengetahui apa saja produk yang ada pada perusahaan tersebut, dan masalah lainnya yaitu ada pada masalah jaringan yang sering mengalami gangguan (tidak bersahabat), sehingga menghambat pemberian pelayanan kepada nasabah.

Konsep pelayanan yang dilakukan oleh Bank Yaitu dengan cara bermasyarakat dan berbaur langsung dengan nasabah dan pelayani dengan sepenuh hati, dan siap mendengarkan keluhan nasabah sehingga karyawan dapat mengatasi masalah yang ada.

Dengan pelayanan yang prima, nasabah akan merasa keanggotaanya memang dibutuhkan dan diperhatikan, sedangkan kepuasan atas pelayanan yang diberikan itu akan menumbuhkan dan meningkatkan loyalitas nasabah. Loyalitas nasabah memang sangat dibutuhkan oleh bank karena pertumbuhan suatu bank itu sendiri sangat tergantung dari pertumbuhan dana yang berasal dari simpanan nasabah, karena kualitas pelayanan dirasakan memiliki hubungan dan dapat mempengaruhi kepuasan nasabah, maka hal inilah yang diangkat menjadi latar belakang dan alasan pemilihan judul penelitian yaitu "Pengaruh Kualitas Pelayanan Terhadap Kepuasan Nasabah Pada PT. Bank Rakyat Indonesia (Persero) Tbk. Unit Bengo Cabang Watampone"

\section{TINJAUAN PUSTAKA \\ a. Kualitas Pelayanan}

Kualitas pelayanan ini menjadi penting karena akan berdampak langsung pada citra perusahaan. Kualitas pelayanan yang baik akan menjadi sebuah keuntungan bagi perusahaan. Bagaimana tidak, jika suatu perusahaan sudah mendapat nilai positif di mata konsumen, maka konsumen tersebut akan memberikan feedback yang baik, serta bukan tidak mungkin akan menjadi pelanggan tetap atau repeat buyer. Maka dari itu, sangat penting untuk mempertimbangkan aspek kepuasan pelanggan terkait kualitas pelayanan yang diberikan. Jenis-jenis pelayanan yang dapat diberikan misalnya berupa kemudahan, kecepatan, kemampuan, dan keramahtamahan yang ditunjukkan 
melalui sikap dan tindakan langsung kepada konsumen.

Tjiptono (2011) Kualitas pelayanan jasa adalah tingkat keunggulan yang diharapkan dan pengendalian atas tingkat keunggulan tersebut untuk memenuhi keinginan pelanggan. Kualitas pelayanan ini adalah upaya pemenuhan kebutuhan yang dibarengi dengan keinginan konsumen serta ketepatan cara penyampaiannya agar dapat memenuhi harapan dan kepuasan pelanggan tersebut. Dalam kualitas pelayanan yang baik, terdapat beberapa jenis kriteria pelayanan, antara lain adalah sebagai berikut:

1) Ketepatan waktu pelayanan, termasuk didalamnya waktu untuk menunggu selama transaksi maupun proses pembayaran.

2) Akurasi pelayanan, yaitu meminimalkan kesalahan dalam pelayanan maupun transaksi.

3) Sopan santun dan keramahan ketika memberikan pelayanan.

4) Kemudahan mendapatkan pelayanan, yaitu seperti tersedianya sumber daya manusia untuk membantu melayani konsumen, serta fasilitas pendukung seperti komputer untuk mencari ketersediaan suatu produk.

5) Kenyaman konsumen, yaitu seperti lokasi, tempat parkir, ruang tunggu yang nyaman, aspek kebersihan, ketersediaan informasi, dan lain sebagainya.

Dari pelayanan di atas dapat disimpulkan bahwa pelayanan merupakan suatu kegiatan dimana perusahaan memberi pelayanan kepada pelanggan sehubungan dengan jasa sehingga dapat menimbulkan kepuasan pelanggan. Pelayanan yang baik dan memuaskan akan mempertinggi citra serta kepercayaan pelanggan terhadap suatu produk atau jasa yang ditawarkan kepada pelanggan. Bila pelayanan yang mereka terima atau nikmati ternyata jauh di bawah dari apa yang mereka harapkan/inginkan, pelanggan akan kehilangan minat terhadap pemberian jasa/pelayanan tersebut. Sebaliknya, jika jasa/pelayanan yang mereka nikmati memenuhi atau bahkan melibihi tingkat kepentingan, maka mereka cenderung akan memakai produk jasa/pelayanan tersebut. Kualitas jasa menurut Lupiyoadi (2006) adalah sejauh mana produk jasa memenuhi spesifikasi-spesifikasinya.

\section{b. Dimensi Kualitas Pelayanan}

Banyak ahli pemasaran yang telah berhasil mengidentifikasi dimensi kualitas pelayanan dari hasil penelitian yang dilakukannya. Diantara para peneliti tersebut ialah Stamatis (Tjiptono, 2007) dalam Asdi (2012) yang berhasil memodifikasi kedelapan dimensi kualitas dari Garvin menjadi tujuh dimensi kualitas pelayanan yaitu:

1) Fungsi (Function), yaitu kinerja primer yang dituntut dari suatu pelayanan.

2) Karakteristik/ciri tambahan (Filtures), yaitu kinerja yang diharapkan atau karakteristik pelengkap.

3) Kesesuaian (Conformance), yaitu kepuasan yang didasarkan pada pemenuhan persyaratan yang telah ditetapkan.

4) Kehandalan (Reliability), yaitu kepercayaan dengan pelanggan dalam kaitan dengan waktu.

5) Dapat diperbaiki (Serviceability), yaitu kemampuan untuk melakukan perbaikan apabila terjadi kekeliruan.

6) Estetika (Aesthetics), Yaitu pengalaman pelanggan yang berkaitan dengan perasaan dan panca indra. 
7) Persepsi (Perception), yaitu reputasi dari kualitas pelayanan.

Dalam salah satu studi mengenai service quality oleh Parasuraman dalam Lupiyoadi, (2006) memiliki 5 dimensi, diantaranya adalah :

\section{1) Tangible}

Tangibles adalah bukti konkret kemampuan suatu perusahaan untuk menampilkan yang terbaik bagi pelanggan. Baik dari sisi fisik tampilan bangunan, fasilitas, perlengkapan teknologi pendukung, hingga penampilan karyawan.

2) Reliability

Reliability adalah kemampuan perusahaan untuk memberikan pelayanan yang sesuai dengan harapan konsumen terkait kecepatan, ketepatan waktu, tidak ada kesalahan, sikap simpatik, dan lain sebagainya.

3) Responsiveness

Responsiveness adalah tanggap memberikan pelayanan yang cepat atau responsif serta diiringi dengan cara penyampaian yang jelas dan mudah dimengerti.

4) Assurance

Assurance adalah jaminan dan kepastian yang diperoleh dari sikap sopan santun karyawan, komunikasi yang baik, dan pengetahuan yang dimiliki, sehingga mampu menumbuhkan rasa percaya pelanggan.

5) Empathy

Empathy adalah memberikan perhatian yang tulus dan bersifat pribadi kepada pelanggan, hal ini dilakukan untuk mengetahui keinginan konsumen secara akurat dan spesifik.

Lima dimensi kualitas pelayanan diatas, banyak digunakan oleh para ahli dalam menjelaskan kualitas pelayanan.
Berdasarkan lima dimensi tersebut, para pelanggan mengevaluasi kualitas pelayanan dengan cara membandingkan pelayanan yang diharapkan dan pelayanan yang dirasakannya. kesenjangan antara pelayanan yang diharapkan dengan yang dirasakan untuk setiap dimensi merupakan ukuran kualitas pelayanan berdasarkan persepsi pelanggan.

\section{c. Pengukuran Kualitas Pelayanan}

Mengukur kualitas pelayanan merupakan suatu tantangan karena kepuasan pelanggan ditentukan oleh banyak faktor yang tak berwujd Menurut Parasuraman (2006) dalam Asdi (2007) ada tiga hal yang patut diperhatikan dalam mengukur kualitas pelayanan, yaitu:

1) Kualitas pelayanan lebih sulit untuk dievaluasi oleh pelanggan dari pada kualitas barang.

2) Mengevaluasi kualitas pelayanan, pelanggan tidak semata-mata melihat dari hasil suatu pelayanan (outcome), tetapi juga mempertimbangkan bagaimana proses pemberian pelayanan.

3) Kriteria kualitas pelayanan yang relevan ialah kriteria yang diterapkan oleh pelanggan. Kualitas pelayanan hanya dapat diukur dari sudut pandang perusahaan.

\section{d. Pengukuran Kepuasan Pelanggan}

Menurut Kotler yang dikutip dari Buku Total Quality Management ada beberapa metode yang dapat digunakan dalam melakukan pengukuran kepuasan pelanggan, diantaranya (Tjiptono, 2003):

1) Sistem keluhan dan saran Organisasi yang berpusat pelanggan (Customer Centered) memberikan kesempatan yang luas kepada para pelanggannya untuk menyampaikan 
saran dan keluhan. Informasiinformasi ini dapat memberikan ideide cemerlang bagi perusahaan dan memungkinkannya untuk bereaksi secara tanggap dan cepat untuk mengatasi masalah-masalah yang timbul.

2) Ghost shopping

Salah satu cara untuk memperoleh gambaran mengenai kepuasan pelanggan adalah dengan mempekerjakan beberapa orang (ghost shopper) untuk berperan atau bersikap sebagai pembeli potensial, kemudian melaporkan temuantemuannya mengenai kekuatan dan kelemahan produk perusahaan dan pesaing berdasarkan pengalaman mereka dalam pembelian produkproduk tersebut. Selain itu para ghost shopper juga dapat mengamati cara penanganan setiap keluhan.

3) Lost customer analysis

Perusahaan seyogyanya menghubungi para pelanggan yang telah berhenti membeli atau yang telah pindah pemasok agar dapat memahami mengapa hal itu terjadi. Bukan hanya exit interview saja yang perlu, tetapi pemantauan customer loss rate juga penting, peningkatan customer loss rate menunjukkan kegagalan perusahaan dalam memuaskan pelanggannya.

4) Survey kepuasan pelanggan

Umumnya penelitian mengenai kepuasan pelanggan dilakukan dengan penelitian survai, baik melalui pos, telepon, maupun wawancara langsung. Perusahaan akan memperoleh tanggapan dan umpan balik secara langsung dari pelanggan dan juga memberikan tanda (signal) positif bahwa perusahaan menaruh perhatian terhadap para pelanggannya.

\section{METODE PENELITIAN.}

\section{a. Teknik Analisis Data}

Data yang berhasil dikumpulkan, kemudian akan diolah dengan metode regresi berganda. Untuk menguji pengaruh variabel independen yaitu pengaruh kualitas pelayanan terhadap variabel dependen yaitu kepuasan nasabah pada PT. Bank Rakyat Indonesia (Persero) Tbk. Unit Bengo Cabang Watampone. Sebelum dilakukan pengujian dengan regresi sederhana, terlebih dahulu dilakukan pengujian dengan beberapa teknik untuk menganalisis data sebagai persyaratan dari metode regresi sederhana. Beberapa teknik tersebut adalah sebagai berikut:

1) Statistik Deskriptif

Menurut Sugiyono (2006), statistik deskriptif adalah statistik yang digunakan untuk menganalisa data dengan cara mendeskripsikan atau menggambarkan data yang telah terkumpul sebagaimana adanya, tanpa bermaksud membuat kesimpulan yang berlaku untuk umum atau generalisasi. Dalam penelitian ini statistik deskriptif berdasarkan karakteristik responden, meliputi: jenis kelamin, umur, pendidikan terakhir, dan pekerjaan.

2) Analisis Regresi linear Sederhana

Analisis regresi linear sederhana digunakan untuk menguji pengaruh variabel independen terhadap variabel dependen dengan skala pengukuran interval dan rasio dalam suatu persamaan linier Nur Indriantoro dan Bambang Supomo (2002).

Rumus persamaan regresi sederhana adalah Singgih Santoso (2000):

$$
\begin{aligned}
& \mathrm{Y}=\mathrm{a}+\mathrm{bx}+\mathrm{e} \\
& \text { Dimana: } \\
& \mathrm{Y}=\text { Kepuasan Konsumen } \\
& \mathrm{a}=\text { Konstanta } \\
& \mathrm{b}=\text { Koefisien Variabel }
\end{aligned}
$$




$$
\begin{aligned}
& \mathrm{x}=\text { Kualitas Pelayanan } \\
& \mathrm{e}=\text { Error }
\end{aligned}
$$

3) Uji Hipotesis

Uji t dikenal dengan uji parsial, yaitu untuk menguji bagaimana pengaruh masing-masing variabel bebasnya secara sendiri-sendiri terhadap variabel terikatnya. Uji statistik t pada dasarnya menunjukkan seberapa jauh pengaruh satu variabel penjelas/independen seacara individual dalam menerangkan variasi variabel dependen (Ghozali 2004). Pengambilan keputusan berdasarkan perbandingan $t$ hitung dengan tabel (Ghozali 2001):

a) Jika statistik dihitung (angka t output) $>$ statistik tabel (tabel t), maka Ho ditolak Ha diterima.

b)Jika statistik hitung (angka t output) < statistik tabel (tabel $\mathrm{t}$ ), maka Ho diterima Ha ditolak.

\section{HASIL DAN PEMBAHASAN}

\section{a. Deskripsi Hasil Penelitian}

Responden pada PT. Bank Rakyat Indonesia (Persero) Tbk. Unit Bengo Cabang Watampone cukup beragam baik dari jenis kelamin, umur, pendidikan terakhir, dan pekerjaan. Dalam penelitian ini menggunakan metode regresi sederhana. Untuk pengelahan data menggukan software SPSS 20. Berikut akan di jelaskan dan dapat dilihat pada penjelasan tiap terlebih dahulu karakteristik responden dalam penelitian ini, yaitu berdasarkan jenis kelamin, umur, pendidikan terakhir, dan pekerjaan.

1) Berdasarkan jenis kelamin

Tingkat jenis kelamin responden yang ada pada PT. Bank Rakyat Indonesia (Persero) Tbk. Unit Bengo Cabang Watampone dapat dilihat pada tabel berikut ini.
Tabel 4.1 Deskripsi Karakteristik

Responden Berdasarkan Jenis Kelamin

\section{Statistics}

\begin{tabular}{|c|c|c|c|c|c|}
\hline $\mathrm{N}$ & & $\begin{array}{l}\text { Valid } \\
\text { Missing }\end{array}$ & & & $\begin{array}{r}84 \\
0\end{array}$ \\
\hline \multicolumn{6}{|c|}{ Jenis Kelamin } \\
\hline & & \begin{tabular}{|l|l|} 
Frequency \\
\end{tabular} & Percent & \begin{tabular}{l|l} 
Valid Percent \\
\end{tabular} & Cumulative Percen \\
\hline & $\begin{array}{l}\text { Laki-Laki } \\
\text { Perempuan } \\
\text { Total }\end{array}$ & \begin{tabular}{l|}
31 \\
53 \\
84
\end{tabular} & $\begin{array}{r}36,9 \\
63,1 \\
100,0\end{array}$ & \begin{tabular}{r|r|}
36,9 \\
63,1 \\
100,0
\end{tabular} & $\begin{array}{r}36 \\
100\end{array}$ \\
\hline
\end{tabular}

Jenis Kelamin

Sumber: Hasil olah data SPSS 20

Berdasarkan pada tabel 4.1 di atas, maka diperolah data dari 84 responden. Bahwa jumlah responden berdasarkan jenis kelamin yang terbanyak adalah jenis kelamin perempuan sebanyak 53 responden atau sebesar 63,1\%. Sedangkan jenis kelamin laki-laki sebanyak 31 responden atau sebesar $36,9 \%$.

Berdasarkan jenis kelamin yang terbanyak adalah jenis kelamin perempuan dikarenakan perempuan yang memegang dan menyimpan penghasilan yang di dapat dari pendapatan suami dan menabungnya ke bank yang telah ia percayai.

2) Berdasarkan umur

Tingkat umur responden yang ada pada PT. Bank Rakyat Indonesia (Persero) Tbk. Unit Bengo Cabang Watampone dapat dilihat pada tabel berikut ini.

Tabel 4.2 Deskripsi Karakteristik

Responden Berdasarkan Umur

\section{Statistics}

\begin{tabular}{|c|c|c|c|c|c|}
\hline $\mathrm{N}$ & \multicolumn{3}{|c|}{ Missing } & & $\begin{array}{r}84 \\
0\end{array}$ \\
\hline \multicolumn{6}{|c|}{ Umur } \\
\hline & & Frequency & Percent & Valid Percent & $\begin{array}{l}\text { Cumulative } \\
\text { Percent }\end{array}$ \\
\hline \multirow{6}{*}{ Valid } & $16-20$ & 7 & 8,3 & 8,3 & \\
\hline & $21-30$ & 28 & 33,3 & 33,3 & 41, \\
\hline & $31-40$ & 21 & 25,0 & 25,0 & 66 \\
\hline & $41-50$ & 19 & 22,6 & 22,6 & 89,3 \\
\hline & $>50$ & 9 & 10,7 & 10,7 & 100,0 \\
\hline & Total & 84 & 100,0 & 100,0 & \\
\hline
\end{tabular}

Umur

Sumber: Hasil olah data SPSS 20 
Berdasarkan pada tabel 4.2, maka dapat dilihat bahwa komposisi tingkat umur responden yang terbanyak adalah berada pada tingkat umur 21 - 30 tahun sebanyak 28 responden dengan persentase sebesar 33,3\%. Kemudian dengan tingkat umur yang terbanyak berada pada masa produktif dimana, dimasa ini responden telah bekerja dan mendapatkan uang sendiri dari hasil keringatnya sendiri kemudian dengan penghasilan yang di dapatnya itu di tabungkan ke bank.

3) Berdasarkan pendidikan terakhir

Tingkat pendidikan terakhir responden yang ada pada PT. Bank Rakyat Indonesia (Persero) Tbk. Unit Bengo Cabang Watampone dapat dilihat pada tabel berikut ini.

Tabel 4.3

Deskripsi Karakteristik Responden

Berdasarkan Pendidikan Terakhir

\section{Statistics}

Pendidikan Terakhir

\begin{tabular}{|c|c|c|c|c|c|}
\hline $\mathrm{N}$ & \multicolumn{3}{|c|}{$\begin{array}{l}\text { Valid } \\
\text { Missing }\end{array}$} & \multicolumn{2}{|r|}{$\begin{array}{r}84 \\
0\end{array}$} \\
\hline \multicolumn{6}{|c|}{ Pendidikan Terakhir } \\
\hline & & Frequency & Percent & $\begin{array}{l}\text { Valid } \\
\text { Percent }\end{array}$ & $\begin{array}{l}\text { Cumulative } \\
\text { Percent }\end{array}$ \\
\hline \multirow{5}{*}{ Valid } & SD & 19 & 22,6 & 22,6 & 22,6 \\
\hline & SMP & 16 & 19,0 & 19,0 & 41,7 \\
\hline & SMA/Sederajat & 34 & 40,5 & 40,5 & 82,1 \\
\hline & Sarjana & 15 & 17,9 & 17,9 & 100,0 \\
\hline & Total & 84 & 100,0 & 100,0 & \\
\hline
\end{tabular}

Sumber: Hasil olah data SPSS 20

Berdasarkan tabel 4.3, maka dapat dilihat bahwa tingkat pendidikan terakhir responden yang terbanyak adalah tingkat pendidikan SMA/Sederajat yakni sebanyak 34 responden dengan persentase sebesar 40,5\%. Di lihat dari tingkat pendidikan terakhir nasabah yang berada pada tingkat SMA/sederajat masih minim sekali dan lebih memutuskan untuk menikah di usia dini dan tidak memanfaatkan untuk mencapai pendidikan agar supaya dapat menjamin kesuksesannya.

4) Bedasarkan pekerjaan
Tingkat pendidikan terakhir responden yang ada pada PT. Bank Rakyat Indonesia (Persero) Tbk. Unit Bengo Cabang Watampone dapat dilihat pada tabel berikut ini.

Tabel 4.4

Deskripsi Karakteristik Responden Berdasarkan Pekerjaan Statistics

Pekerjaan

\begin{tabular}{|ll|r|}
\hline $\mathrm{N}$ & Valid & 84 \\
& Missing & 0 \\
\hline
\end{tabular}

\begin{tabular}{|c|c|c|c|c|c|}
\hline \multicolumn{6}{|c|}{ Pekerjaan } \\
\hline & & Frequency & $\begin{array}{l}\text { Percent } \\
\end{array}$ & $\begin{array}{l}\text { Valid } \\
\text { Percent }\end{array}$ & $\begin{array}{c}\text { Cumulative } \\
\text { Percent }\end{array}$ \\
\hline \multirow{6}{*}{ Valid } & $\begin{array}{l}\text { Wiraswasta } \\
\text {. }\end{array}$ & 15 & $\overline{17,9}$ & 17,9 & 17,9 \\
\hline & Ibu Rumah Tangga & 32 & 38,1 & 38,1 & 56,0 \\
\hline & Pelajar/Mahasiswa & 8 & 9,5 & 9,5 & 65,5 \\
\hline & $\begin{array}{l}\text { Pegawai Negeri Sipil } \\
\text { (PNS) }\end{array}$ & 11 & 13,1 & 13,1 & 78,6 \\
\hline & Lainnya & 18 & 21,4 & 21,4 & 100,0 \\
\hline & Total & 84 & 100,0 & 100,0 & \\
\hline
\end{tabular}

Sumber: Hasil olah data SPSS 20

Berdasarkan tabel 4.4, maka dapat dilihat jumlah responden yang terbanyak berdasarkan pekerjaan adalah dari kalangan ibu rumah tangga yakni sebanyak 32 responden dengan persentase sebesar 38,1\%. Kemudian dari tingkat pekerjaan lebih banyak dari kalangan ibu rumah tangga yang menjadi nasabah dikarenakan uang dan pendapatan suami maupun penghasilan yang di dapat sendiri mereka yang memegang dan mengelolah keuangan dalam rumah tangga mereka dan sebagian penghasilan dan pendapatan di tabungkan ke bank yang terdekat dan telah mereka percayai dari tingkat keamanannya.

\section{a. Pengaruh Kualitas Pelayanan Terhadap Kepuasan Nasabah Pada PT. Bank Rakyat Indonesia (Persero) Tbk. Unit Bengo Cabang Watampone}

Model analisis data yang digunakan yaitu analisis regresi sederhana dengan 
bantuan SPSS. Analisis regresi sederhana merupakan hubungan antara dua variabel yaitu variabel bebas (variable independen) dan Variabel tidak bebas (variable dependen).

1) Uji validasi

Sebagaimana telah disinggung pada bab terdahulu, bahwa uji validitas (uji kesahihan) digunakan untuk mengetahui apakah koesioner yang disusun tersebut itu sudah valid atau sahih, maka perlu diuji dengan uji korelasi antara skor nilai tiap-tiap item pertanyaan dengan skor total koesioner tersebut. Untuk item-item pertanyaan yang tidak valid harus dibuang atau tidak dipakai sebagai instrumen pertanyaan, hasil uji validasi dapat dilihat sebagai berikut:

Tabel 4.5 Uji Validasi

\begin{tabular}{|l|c|c|c|}
\hline \multicolumn{1}{|c|}{ Variabel } & Nilai R hitung & Nilai R tabel & Keterangan \\
\hline X1.1 & 0,511 & 0,220 & Valid \\
\hline X1.2 & 0,363 & 0.220 & Valid \\
\hline X1.3 & 0,521 & 0,220 & Valid \\
\hline X1.4 & 0,511 & 0,220 & Valid \\
\hline X1.5 & 0,690 & 0,220 & Valid \\
\hline X1.6 & 0,550 & 0,220 & Valid \\
\hline X1.7 & 0,582 & 0,220 & Valid \\
\hline X1.8 & 0,686 & 0,220 & Valid \\
\hline X1.9 & 0,697 & 0,220 & Valid \\
\hline X1.10 & 0,681 & 0,220 & Valid \\
\hline Y1.1 & 0,756 & 0,220 & Valid \\
\hline Y1.2 & 0,813 & 0,220 & Valid \\
\hline Y1.3 & 0,819 & 0,220 & Valid \\
\hline Y1.4 & 0,756 & 0,220 & Valid \\
\hline Y1.5 & 0,498 & 0,220 & Valid \\
\hline
\end{tabular}

Sumber: Hasil olah data SPSS 20

Berdasarkan data pada tabel 4.5 diatas tersebut, dengan melihat nilai Pearson Correlation antara variabel X dan variabel $\mathrm{Y}$ berada pada taraf signifikan korelasi sebesar 0,05, maka dapat dinyatakan bahwa item-item pertanyaan untuk variabel $X$ dan variabel $Y$ dinyatakan valid.

a) Uji Reliabilitas

Reliabilitas merupakan alat ukur suatu kestabilan dan konsistensi responden dalam menjawab hal-hal yang berkaitan dengan pertanyaan yang merupakan dimensi suatu variabel yang disusun dalam bentuk koesioner. Suatu instrumen koesioner dikatakan handal (reliabel) apabila memiliki koefisien kehandalan (cronbach alpha) sebesar 0,60 atau lebih. Jika nilai reliabilitas > nilai cronbach alpha 0,60 maka pertanyaan koesioner dikatakan reliabel.

Tabel 4.6 Uji Reliability

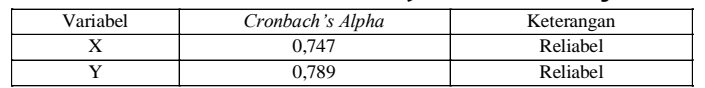

Sumber: Hasil olah data SPSS 20

Berdasarkan data pada tabel 4.6, hasil uji reliabilitas diperoleh nilai koefisien reliabilitas variabel $\mathrm{X}$ sebesar 0,747 dan variabel Y sebesar 0,789 memiliki angka koefisien atau nilai Cronbach's Alpha yang lebih besar dari 0,60, maka dapat disimpulkan bahwa semua item-item pertanyaan untuk variabel $\mathrm{X}$ dan variabel $\mathrm{Y}$ dinyatakan reliabel.

b) Metode Analisis Regresi Liner Sederhana

Selanjutnya akan dilakukan pengolahan data dengan menggunakan metode analisis data regresi liner sederhana dengan bantuan SPSS. Analisis regresi linear sederhana merupakan hubungan antara dua variabel yaitu variabel bebas (variable independen) dan variabel tidak bebas (variable dependen). Regresi linear sederhana digunakan untuk mendapatkan hubungan matematis dalam bentuk suatu persamaan antara variabel tidak bebas dengan variabel bebas. Bentuk umum dari persamaan regresi linear untuk populasi adalah:

$$
\begin{aligned}
& \mathrm{Y}=\mathrm{a}+\mathrm{bx}+\mathrm{e} \\
& \text { Dimana: } \\
& \mathrm{Y} \quad=\text { Kepuasan Konsumen } \\
& \mathrm{a} \quad=\text { Konstanta } \\
& \mathrm{b} \quad=\text { Koefisien variabel } \\
& \mathrm{X} \quad=\text { Kualitas Pelayanan } \\
& \mathrm{e} \quad=\text { Error/Faktor Kesalahan }
\end{aligned}
$$


Dalam melakukan perhitungan analisis regresi linear semua data diolah menggunakan aplikasi SPSS versi 20 . Adapun hasil analisis data yang diperoleh dari pengolahan data SPSS adalah sebagai berikut:

Tabel 4.7 Model Summary Model Summary

\begin{tabular}{|c|c|c|c|c|c|c|c|c|c|}
\hline \multirow[t]{2}{*}{ Model } & \multirow[t]{2}{*}{$\mathrm{R}$} & \multirow{2}{*}{\begin{tabular}{|c|}
$\mathrm{R}$ \\
Square
\end{tabular}} & \multirow{2}{*}{$\begin{array}{l}\text { Adjusted } \\
\text { R Square }\end{array}$} & \multirow{2}{*}{\begin{tabular}{|c} 
Std. \\
Error of \\
the \\
Estimat \\
$\mathrm{e}$
\end{tabular}} & \multicolumn{5}{|c|}{ Change Statistics } \\
\hline & & & & & $\begin{array}{c}\text { R Square } \\
\text { Change }\end{array}$ & \begin{tabular}{c|}
$\mathrm{F}$ \\
Change
\end{tabular} & $\mathrm{dfl}$ & df2 & $\begin{array}{c}\text { Sig. F } \\
\text { Chan } \\
\text { ge }\end{array}$ \\
\hline 1 &, $646^{a}$ & ,418 & ,411 & 2,033 & ,418 & 58,806 & 1 & 82 & $\overline{, 000}$ \\
\hline
\end{tabular}

Sumber: Hasil olah data SPSS 20

Dari hasil perhitungan SPSS diperoleh $\mathrm{R}=$ 0,646 , dengan $R^{2}=0,418$. Nilai $R$ merupakan hubungan antara kualitas pelayanan dan kepuasan nasabah, sedangkan untuk mengetahui seberapa besar kualitas model regresi linear yang terbentuk, maka diperhatikan nilai koefisien determinasi ( $\mathrm{R}$ square) $=0,418$, Nilai tersebut menunjukkan informasi bahwa 41,8\%, dari besarnya kepuasan nasabah telah dijelaskan pada data kualitas pelayanan. Sedangkan sisanya yaitu $58,2 \%$ informasi mengenai besarnya kepuasan nasabah belum dapat dijelaskan oleh variabel-variabel bebas tersebut.

\section{Tabel 4.8 ANOVA}

\begin{tabular}{|c|c|c|c|c|c|}
\hline \multicolumn{6}{|c|}{ ANOVA $^{a}$} \\
\hline Model & Sum of Squares & $\mathrm{Df}$ & $\begin{array}{c}\text { Mean } \\
\text { Square }\end{array}$ & $\mathrm{F}$ & Sig. \\
\hline Regression & 243,081 & 1 & 243,081 & 58,806 &, $000^{\mathrm{b}}$ \\
\hline 1 Residual & 338,955 & 82 & 4,134 & & \\
\hline Total & 582,036 & 83 & & & \\
\hline
\end{tabular}

a. Dependent Variable: Kepuasan Nasabah

b. Predictors: (Constant), Kualitas Pelayanan

Sumber: Hasil olah data SPSS 20

Derajat bebas pembilang $=\mathrm{k}-1=2-1=1$ Derajat bebas penyebut $=\mathrm{n}-\mathrm{k}=84-2=$ 82

Maka F tabel $0,05(1 ; 82)=3,96$

Pada tabel 4.8 diketahui bahwa nilai F hitung sebesar 58,806 dan F tabel 3,96, maka dapat disimpulkan bahwa apabila $\mathrm{F}$ hitung > F tabel maka variabel bebas (independen) berpengaruh positif signifikan terhadap variabel terikat (dependen).

Tabel 4.9 Coefficients

Coefficients $^{\mathrm{a}}$

\begin{tabular}{|c|c|c|c|c|c|c|}
\hline & \multirow[t]{2}{*}{ Model } & \multicolumn{2}{|c|}{$\begin{array}{c}\text { Unstandardized } \\
\text { Coefficients }\end{array}$} & \multirow{2}{*}{$\begin{array}{c}\begin{array}{c}\text { Standardized } \\
\text { Coefficients }\end{array} \\
\text { Beta } \\
\end{array}$} & \multirow[t]{2}{*}{$\mathrm{T}$} & \multirow[t]{2}{*}{ Sig. } \\
\hline & & B & Std. Error & & & \\
\hline & (Constant) & 3,341 & 1,975 & & 1,692 &, 095 \\
\hline 1 & $\begin{array}{l}\text { Kualitas } \\
\text { Pelayanan }\end{array}$ & 404 & 053 & 646 & 7,669 & 000 \\
\hline
\end{tabular}

Sumber: Hasil olah data SPSS 20

Pada tabel 4.9 tersebut, digunakan untuk melihat uji koefisien. Diketahui bahwa nilai signifikan untuk pengaruh kualitas pelayanan $(\mathrm{X})$ terhadap kepuasan nasabah (Y) adalah sebesar 0,000 $<0,05$ dari hasil $\mathrm{t}$ hitung $7.669>\mathrm{t}$ tabel sebesar 1.98932, sehingga dapat disimpulkan hahwa kualitas pelayanan memiliki pengaruh yang positif terhadap kepuasan nasabah. Taraf kesalahan sebesar 5\% atau 0,05, maka akan dilakukan dengan uji hipotesis:

Ho = ada pengaruh kualitas pelayanan terhadap kepuasan nasabah PT. Bank Rakyat Indonesia (Persero) Tbk. Unit Bengo Cabang Watampone.

$\mathrm{Ha}=$ tidak ada pengaruh kualitas pelayanan terhadap kepuasan nasabah PT. Bank Rakyat Indonesia (Persero) Tbk. Unit Bengo Cabang Watampone.

Dari nilai persamaan yang dihasilkan oleh regresi diperoleh nilai persamaan sebagai berikut:

a. Kinerja karyawan $=7,669+0,404$

b. Nilai konstanta sebesar 1,692 dan dinyatakan jika tidak ada variabel bebas maka kepuasan nasabah juga sebesar 1,692.

c) Nilai koefisien sebesar 0,404 dan menunjukkan bahwa meningkatnya kualitas pelayanan sebesar $1 \%$ dan akan meningkatkan kepuasan nasabah sebesar 0,404. Nilai uji t menunjukkan bahwa tingkat signifikan konstanta 
dan variabel independen, sig $=0,000<$ 0,05 ini mempengaruhi secara signifikan dalam regresi linear sederhana. Dengan demikian pengujian statistik ini dapat disimpulkan bahwa terdapat pengaruh signifikan kualitas pelayanan terhadap kepuasan nasabah pada PT. Bank Rakyat Indonesia (Persero) Tbk. Unit Bengo Cabang Watampone yang di tunjukkan dengan angka yang signifikan 0,00 0,05 ada tabel model summary berdasarkan hasil analisis yang telah dilakukan, maka hipotesis yang diajukan sebelumnya dinyatakan dapat diterima.

\section{PENUTUP}

\section{a. Simpulan}

Berdasarkan pada hasil analisis data mengenai pengaruh kualitas pelayanan terhadap kepuasan nasabah dimana hasil pengujian terhadap hipotesis Ho menunjukkan bahwa ada pengaruh kualitas pelayanan terhadap kepuasan nasabah PT. Bank Rakyat Indonesia (Persero) Tbk. Unit Bengo Cabang Watampone. Nilai koefisien kualitas pelayanan sebesar 0,404 dengan nilai $t$ hitung $7.669>\mathrm{t}$ tabel sebesar 1.98932 dan tingkat signifikan sebesar $1 \%$. Hal ini menunjukkan bahwa kualitas pelayanan berpengaruh terhadap kepuasan nasabah. Dengan demikian hal ini membuktikan bahwa tindakan pelayanan yang dilakukan memberikan pengaruh yang posistif terhadap kepuasan nasabah.

\section{b. Saran}

Berdasarkan kesimpulan dalam penelitian ini maka saran yang dapat diberikan adalah:

1. penelitian ini dapat menjadi bahan pertimbangan dalam menentukan kebijakan strategi yang akan diambil oleh perusahaan diwaktu yang akan datang. Khususnya bagi pihak PT. Bank Rakyat Indonesia (Persero) Tbk. Unit Bengo Cabang Watampone selaku perusahaan pengelola.

2. Disarankan agar dalam meningkatkan kepuasan nasabah maka pihak manajemen perusahaan sebaiknya meningkatkan kualitas pelayanan kepada nasabah, selain itu dengan menambah sarana dan prasarana ruang pelayanan agar pelanggan atau nasabah yang datang dapat merasa nyaman terutama dalam segi fasilitas, misalnya kursih harus di perbanyak sehingga nasabah dapat menunggu dan mengantri dengan perasaan yang nyaman.

3. Adanya pengaruh kualitas pelayanan terhadap kepuasan nasabah maka disarankan agar dimasa yang akan datang, penerapan kualitas pelayanan semakin di tingkatkan oleh pihak PT. Bank Rakyat Indonesia (Persero) Tbk. Unit Bengo Cabang Watampone agar semakin meningkatkan kepuasan nasabah serta dapat memacu kenaikan jumlah nasabah yang berarti juga akan meningkatkan output perusahaan, misalnya kecepatan waktu pelayanan lebih di tingkatkan lagi dan mengatasi masalah jaringan yang ada agar tidak menghambat proses kerja karyawan dalam melayani pelanggan atau nasabah.

\section{DAFTAR PUSTAKA}

Ainul, Yaqin \& Aniek Maschudah Ilfitriah. 2014. Pengaruh Kualitas Pelayanan Terhadap Kepuasan Dan Loyalitas Nasabah Bank Pengguna E-Banking Di Surabaya. Journal of Business and Banking, Volume 4, No. 2. Surabaya. 
(digilib.mercubuana.ac.id)

Asdi. 2012. Pengaruh Dimensi Kualitas Pelayanan Terhadap Kepuasan Pasien Pada Rumah Sakit Umum Daerah Syekh Yusuf Sungguminasa Kabupaten Gowa. Jurnal Manajemen Profitability. Makassar.

(http://www.academia.edu)

Brata. 2003. Dasar-Dasar Pelayanan Prima. Editor Rayendra L. Toruan. Jakarta: Penenrbit PT Elex Media Komputindo Kelompok Gramedia.

Dwi, Aryani dan Febrina Rosinta. 2010. Pengaruh Kualitas Pelayanan Terhadap Kepuasan Pelanggan Dalam Membentuk Loyalitas Pelanggan. Jurnal Ilmu Administrasi dan Organisasi, Volume 17, No. 2.

(Journal.ui.ac.id)

Giese \& Cote. 2000. Academy Of Marketing Science Review. Defining Consumer.

Hendro, Ir. 2011. Dasar-Dasar Kewirausahaan. Jakarta: Penerbit Erlangga.

Husnul, Andi Asrul. 2014. Pengaruh Kualitas Pelayanan Terhadap Kepuasan Nasabah PT. Bank Pembangunan Daerah Sulawesi Selatan \& Sulawesi Barat Cabang Jeneponto.Skripsi.

(http://respository.unhas.ac.id)

Kasmir. 2005. Etika Custumer Service. edisi pertama. cetakan pertama. Jakarta: Penerbit Raja Grafindo Persada,

Kotler Philip dan A.B. Susanto. 2000. Manajemen Pemasaran, Edisi Kesebelasan Jilid 1, Alih Bahasa Benyamin Molan, Editor Yenna Waldemas. Jakarta Indeks.

Loina. 2001. Hubungan Masyarakat Membina Hubungan Baik Dengan Publik.

Lupiyoadi, Hamdani. 2006. Manajemen Pemasan Jasa. Edisi Kedua. Jakarta: Penerbit Salemba Empat.
Misna, 2018. Pengaruh Kualitas Layanan Terhadap Kepuasan Nasabah Bertransaksi Pada PT. Bank Rakyat Indonesia (Persero) Tbk,Cabang Kabupaten Barru. Skripsi

Nining, Catur Pawestriningtyas, dkk. 2016. Pengaruh Kualitas Pelayanan Jasa Terhadap Kepuasan Nasabah (Survei Pada Nasabah Perum Pegadaian Kantor Cabang Syariah Tlogomas Malang). Jurnal Administrasi Bisnis (JAB) Vol. 32 No. 2.

(http://media.neliti.com)

Nur, Fajri. 2018. Pengaruh Kualitas Pelayanan Karyawan Terhadap Tingkat Kepuasan Nasabah Pada Bank BTPN Cabang Sungguminasa Kabupaten Gowa. Skripsi.

Singgih Santoso. 2000. Statistika Untuk Penelitian. Alfabeta. Bandung

Tjiptono. 2011. Sistem Manajemen Strategic. Jakarta.

Tjiptono, Fandy dan Gregorius Chandra. 2005. Service, Quality dan Satisfaction. Penerbit : Andi, Yogyakarta

Tjiptono, Fandy dan Anastasia Diana. 2003. Total Quality Manajemen. Edisi Revisi. Andy: Yogyakarta

Tjiptono, Fandy.2004. Prinsip-Prinsip Total Quality Service. Yogyakarta: Andi Offset.

Undang-Undangan. No. 10 Tahun 1988,Pokok Perbankan.

Zurni, Zahara Samosir. 2005. Pengaruh Kualitas Pelayanan Terhadap Kepuasan Mahasiswa Menggunakan Perpustakaan USU. Jurnal Studi Perpustakaan dan Informasi, Vol. 1, No. 1.

(repository.usu.ac.id)

http//contohskripsikoe.blokspot.com/20 $13 / 02$ 